\title{
Air Passenger Transport In The APEC: Regulatory Impacts and Prospects for Asia Pacific Integration
}

\author{
Massimo Geloso Grosso \\ The OECD Trade and Agriculture Directorate
}

\begin{abstract}
This study aims at assessing the prospects for a more liberal air passenger transport regime in the Asia Pacific region under the auspices of the Asia Pacific Economic Cooperation (APEC). The decades-old bilateral air services regime has been under pressure to reform for several years. Notwithstanding the critical role that international air transport plays in the ongoing integration of Asia Pacific economies, the airline industry remains one of the region's most heavily regulated. Estimates from the gravity equation employing the Air Liberalization Index (ALI) developed by the World Trade Organization (WTO) Secretariat find a positive and statistically significant relationship between relaxing bilateral air services restrictions and air passenger traffic. The results hold for a wide range of specifications controlling for fixed effects, different sample sizes, and for all variants of the ALI. The preferred specification, the Anderson and Van Wincoop (2003) equation, provides the most conservative estimates. Prior to taking account of general equilibrium effects, the results imply that if APEC economies eased air transport restrictions to double the ALI scores with their aviation partners, both within and outside the APEC region, traffic would increase by $4.5 \%$.
\end{abstract}

- JEL Classification: F13, F15, L93

- Keywords: Air transport, Asia Pacific, Trade Policy

\footnotetext{
*Corresponding address: Massimo Geloso Grosso; Tel: +33(0)145248924; Fax: +33(0)144306163; E-mail: massimo.geloso-grosso@oecd.org; Postal address: 5 rue de Marronniers, 75016 Paris. (C2012-Center for Economic Integration, Sejong Institution, Sejong University, All Rights Reserved.
} 


\section{Introduction}

Air transport services' development as one of the most dynamic recent growths in all sectors in the transport industry has proven vital to the international trade of both goods and services. Air conveyance often represents the only viable means of transport to remote, peripheral regions and landlocked countries, particularly in the developing world in light of more limited land transport infrastructure. International transport is considered a prerequisite for the development of tourism, accounting in developing countries for nearly $80 \%$ of international tourist arrivals (UNESCAP, 2005). Air transport is also at the core of developments in transnational production and just-in-time supply management, and a key determinant in meeting the demand for time-sensitive products, such as perishable goods, textiles and clothing, and electronics.

The Asia Pacific region has seen solid expansion in air passenger transport, notwithstanding the intervention of recent external events, currently accounting for over a quarter of world traffic (see Figure 1). The rapid growth of Asian airlines, which in the past accounted for a tiny share of world traffic, has brought about considerable changes in the structure of the international industry. Hong Kong, China, and Singapore, although featuring a non-existent domestic market, rank very high in the world in terms of international traffic. China has experienced burgeoning growth; it is already the fifth largest passenger market and is projected to become in the next two decades the second largest aviation market in the world. According to the International Civil Aviation Organization (ICAO), 11 APEC economies are in the top 20 list in terms of international operations.

The Asia Pacific region is also predicted to become the largest world air transport market in the near future, in light of its growing economic importance, population, and geography. The region has experienced the highest GDP growth rates during the last decade or so, driven by China's robust growth. As a whole, APEC's GDP experienced an average annual increase of $4.9 \%$ between 1995 and 2005 (CAPA, 2007). The relatively long distances in the region, its many islands and slow development in alternative transport modes, such as high speed trains, make air transport the most practical means of travel. Considerable air service connectivity potential remains, given that only a few APEC economies have multiple hub systems. For example, Indonesia, in addition to its archipelagos, has dozens of cities with more than one million people, but its international connectivity remains at relatively low levels (PATA, 2007). 
Figure 1. Passenger traffic by region

1985

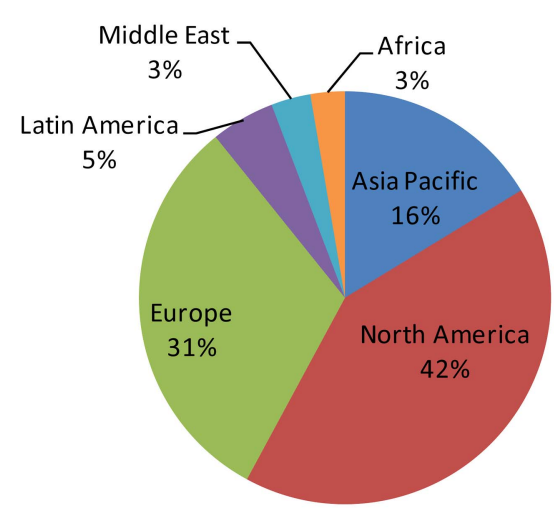

2009

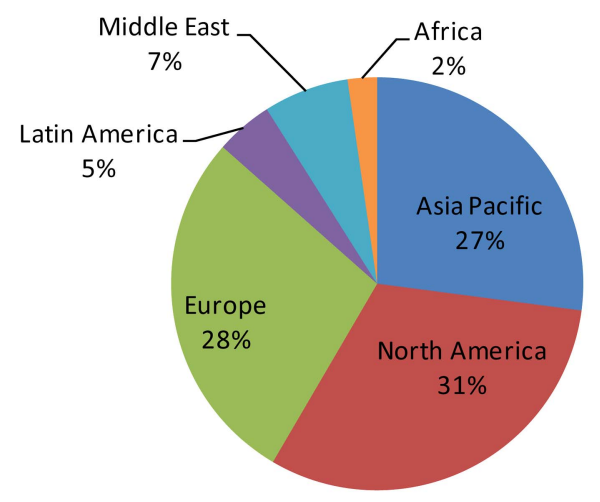

Source: ICAO.

The region therefore seems well placed to take advantage of future liberalization to lower trade costs within the framework of bilateral, regional, and multilateral initiatives. Interest in reforming the decades-old system established at the Chicago Conference is growing among airlines since the system imposes constraints on their operations and ability to reduce costs, and may be one of the factors explaining the limited profits registered by the industry (Findlay and Round, 2006). The tourism sector, and in general increasing consumer influence, represents an additional important factor. In the Asia Pacific region, in particular, rising middle class population and a more aware consumer environment means that governments in the region have to pay more attention to their interests when formulating aviation policy decisions (Zainal-Abidin et al., 2005).

This paper assesses the prospects for a more open air passenger transport regime in the Asia Pacific region under the auspices of APEC. The next section provides some background on the regulation of air passenger transport in the region, followed by estimates on the impact of enhanced market openness in the sector by APEC economies with the last section assessing the importance of reducing air transport services impediments to enhance international trade in the APEC region. 


\section{Background on the Regulation of Air Passenger Transport in APEC}

Figure 2 below presents the average level of aviation openness for APEC economies, as proxied by the ALI developed by the WTO Secretariat (WTO, 2006; and WTO, 2007). The ALI is based on the World Air Services Agreement (WASA) database published by ICAO in 2005. The figure shows that the US, Chile, and New Zealand have the most open regimes, while China and Russia are among the most restrictive. ${ }^{1}$ Some progress has been achieved in easing restrictions by APEC economies within the bilateral framework, particularly through the emergence of open skies agreements over the last decades yet significant restrictions remain in place, which constrain the ability of carriers to develop their networks according to market conditions, or to merge and approach the international financial markets for capital.

In general, the data indicate that open $3^{\text {rd }}$ and $4^{\text {th }}$ freedom rights are granted in a large number of bilateral air services agreements (ASAs) signed by APEC

Figure 2. Average levels of aviation openness by APEC economy

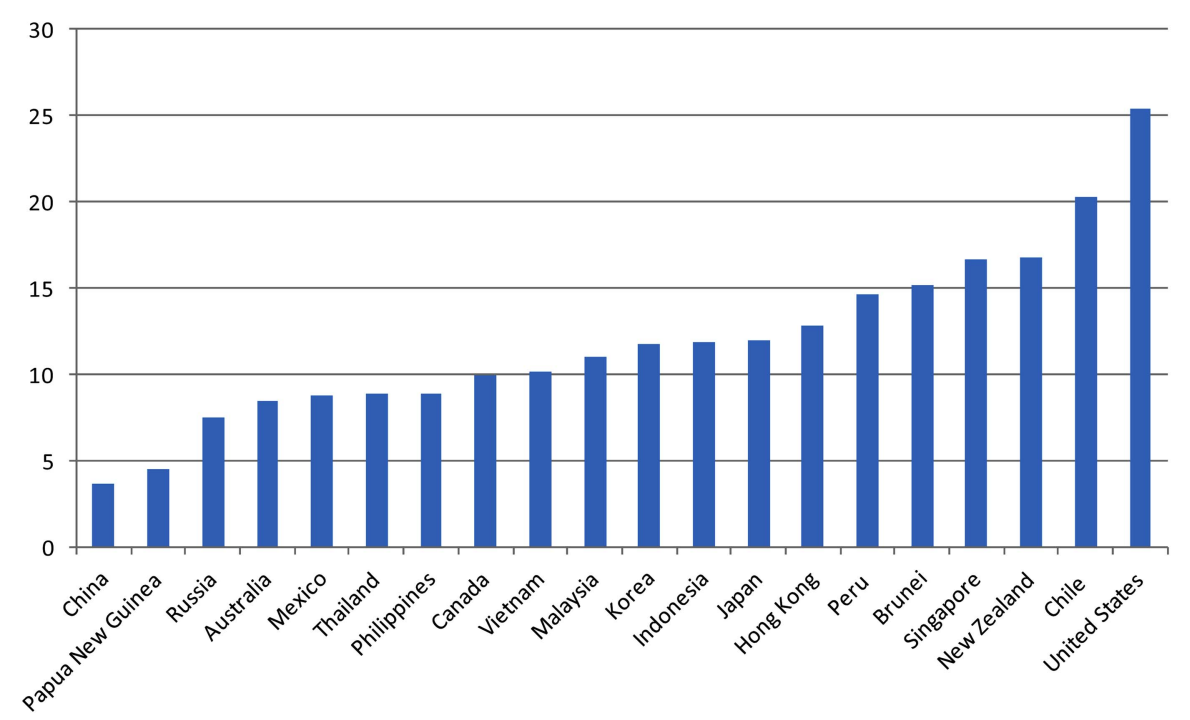

Source: WTO.

\footnotetext{
${ }^{1}$ The value of the ALI ranges between zero for very restrictive agreements and 50 for very liberal ones. The bilateral scores have been averaged here (with available data for partner countries) to present indicators of restrictiveness by country.
} 
economies. Restrictions to $5^{\text {th }}$ freedom rights remain prevalent, with $7^{\text {th }}$ freedom and cabotage being very rarely granted. Open route schedules are included in only a few agreements, though there seems to be a trend towards adoption of multiple gateways policy in some countries, particularly to develop tourism destinations. Some pluritareal ASAs have liberalized provisions in this area.

Airline designation represents the area where it appears that most progress has been achieved. Double or multiple designation has become commonplace in bilateral and plurilateral agreements. On the other hand, ownership and control rules are perhaps the most difficult issues to tackle. Bilateral and plurilateral ASAs largely maintain a conservative approach in this area, typically providing for the most restrictive substantial ownership and control requirement.

APEC economies also retain a generally restrictive stand with respect to tariff provisions. Dual approval of tariffs remains widely in place in bilateral ASAs, though some headway has been made in liberalizing tariff provisions and filing requirements in plurilateral agreements. Provisions on capacity also remain restrictive, with Predetermination and Bermuda I clauses making up the majority of bilateral ASAs.

Cooperative arrangements, particularly code-sharing, are generally allowed in both bilateral and plurilateral ASAs in the region. Some agreements also provide for third-party code-sharing. Finally, progress has been made in liberalizing charter provisions in ASAs in recognition of the importance of these operators to foster tourism development, though restrictions remain in place reflecting the perception that they may divert traffic of scheduled services.

\section{The Impact of Liberalizing Air Transport Services in APEC}

Despite the growing importance of air transport as a facilitator of international trade, relatively little formal research has analyzed the impact of international liberalization (or lack thereof) on the industry. Earlier work focused on the impact of ASAs on airfares. Building on research by Gonenc and Nicoletti (2000), Doove et al. (2011) show that restrictiveness is associated with higher prices of up to $22 \%$ in some Asia Pacific economies. Micco and Serebrisky (2004) represent one of the first attempts to employ the gravity model to study the potential impact of reforming aviation. The study finds that the long-term effect of signing open skies agreements is to reduce air freight costs by around $8 \%$.

More recently, a body of research has emerged using the ALI (or variants of it) 
developed by the WTO Secretariat. Achard (2009) employs a gravity model to estimate the impact of regulation on air cargo flows, using data collected by the International Air Transport Association (IATA) on the top 100 routes worldwide. The study provides evidence that air transport liberalization is associated with larger bilateral cargo flows. Geloso Grosso and Shepherd (2011) assess the link between a more liberal air cargo regime and increased bilateral merchandise trade in the Asia Pacific region. They find that air services policies are associated with higher bilateral trade in merchandise, particularly for manufactured goods, time sensitive products, and parts and components.

This paper employs the ALI in a gravity-type model to analyze the effects of air transport liberalization on air passenger traffic. ${ }^{2}$ It differs from existing work on restrictiveness in air passenger transport by focusing on a single region (APEC) where air transport is particularly important, and employs a broader range of specifications and robustness checks to more fully analyze the impact of liberalization for APEC economies.

In particular, a common shortcoming of studies that analyze the effects of air passenger services reform is that of hetereskedasticity in the original non-linear model (Santos and Tenreyro, 2006). This study employs the Park test proposed by Santos and Tenreyro (2006) Eq. (13) to deal with this problem. In the absence of such test, there is no basis to determine which estimator is the most appropriate for a given dataset. This is important since, unlike standard heteroskedasticity, which can lead to bias in the estimated variance-covariance matrix only, this type of heteroskedasticity can produce serious bias in the coefficient estimates as well.

\section{A. Methodology}

The methodology used in this study is a gravity model based on the theoretical underpinning recently provided by Anderson and Van Wincoop (2003). The model explains bilateral flows as a function of the market size of trading partners, the distance between them and a number of other geographical and institutional variables. It is a useful model to analyze the effects of air services regulation on trade flows since it includes trade costs (natural and related to policy) as determinants of bilateral trade flows.

The gravity model is estimated employing country-pair traffic as the endogenous variable. It takes the following form:

\footnotetext{
${ }^{2}$ Piermartini and Rousová (2008) employ a similar methodology to a worldwide sample of countries.
} 


$$
\log \left(P T_{i j}\right)=\log \left(E_{j}\right)+\log \left(Y_{i}\right)-\log (Y)+(1-\sigma) \log \left(t_{i j}\right)-(1-\sigma) \log \left(P_{j}\right)-(1-\sigma) \log \left(\prod \mathrm{i}\right)+\varepsilon_{i j}
$$

where $P T_{i j}$ is the total number of passengers travelling between country $i$ and country j; $E_{j}$ and $Y_{i}$ are respectively country j's expenditure and country i's production $^{3} ; Y$ is worldwide output; $\sigma$ is the intra-sectoral elasticity of substitution (i.e. the elasticity of substitution among product/service varieties within a sector) ${ }^{4}$; $t_{i j}$ is the bilateral trade costs function; and $\varepsilon_{i j}$ is the error term. The two terms $\left(P_{j}\right)^{1-\sigma}=\sum_{i=1}^{N} \Pi_{i}^{\sigma-1} \omega_{i}\left(t_{i j}\right)^{1-\sigma}$ and $\left(\Pi_{j}\right)^{1-\sigma}=\sum_{i=1}^{N} P_{j}^{\sigma-1} \omega_{j}\left(t_{i j}\right)^{1-\sigma}$, with $\omega_{i}$ being the country's share in global ( $N$ countries) output or expenditure, represent respectively inward and outward "multilateral resistance." The first of these terms captures the dependence of j's imports on trade costs across all providers, while the second captures the dependence of i's exports on trade costs across all destination markets. One possibility to take account of multilateral resistance is to augment the traditional gravity equation with exporter and importer fixed effects, which leads to:

$$
\log \left(P T_{i j}\right)=c+\sum_{i=1}^{N} d_{i}+\sum_{j=1}^{N} f_{i}+(1-\sigma) \log \left(t_{i j}\right)+\varepsilon_{i j}
$$

where the $\mathrm{d}$ and $\mathrm{f}$ terms are, respectively, reporter and partner-country fixed effects. Country-specific variables, such as the size of the economy, which do not vary across partner countries are dropped from the estimating equation as these are accounted for in the respective fixed effects. Hence, what remains is to specify the trade cost function $t$. The analysis uses the ALI as the policy variable, along with distance and several other controls such as common language, a binary variable which is unity if the country pair has the same language; common border, a binary variable which is unity if the country pair shares a border; historic tie, a binary variable which is unity if the country pair has historic ties; island, a binary variable which is unity if the country is an island; and existing direct service, a binary variable which is unity if the country pair has a direct service. Thus:

$$
\begin{aligned}
& \log \left(t_{i j}\right)=\beta_{1} \log \left(\text { ALI }_{i j}\right)+\beta_{2} \log \left(\text { distance }_{i j}\right)+\beta_{3} \text { common languate }_{i j}+\beta_{4} \text { common } \\
& \text { border }_{i j}+\beta_{5} \text { existing direct servive }_{i j}+\beta_{6} \text { island }_{i}+\beta_{7} \text { island }_{j}+\beta_{8} \text { historic ti }_{i j}
\end{aligned}
$$

\footnotetext{
${ }^{3}$ Although the dependent variable is symmetric, a distinction is made here between exporter and importer for simplicity.

${ }^{4}$ The consumer's preferences take the Dixit-Stiglitz "love of variety" form in the Anderson and Van Wincoop (2003) model. For a simple derivation of the model see Baldwin and Taglioni, 2006 (pages 2-6).
} 
Silva and Tenereyro (2006) suggest estimating the gravity model in its multiplicative form and propose the Poisson pseudo maximum likelihood (PPML) estimation technique. This approach is useful to include observations for which traffic is zero and, more importantly here, can generate more precise estimates in the presence of heteroskedasticity in the original non-linear model. In addition to ordinary least squares (OLS), the gravity equation is thus estimated using the PPML. Substituting (3) into (2), the empirical specification is the following:

$\log \left(P T_{i j}\right)=\beta_{0}+\beta_{1} \log \left(A L I_{i j}\right)+\beta_{2} \log \left(\right.$ distance $\left._{i j}\right)+\beta_{3}$ common languate $_{i j}+\beta_{4}$ common border $_{i j}+\beta_{5}$ existing direct servive $_{i j}+\beta_{6}$ historic tie $_{i}+\sum_{i=1}^{N} d_{i}+\sum_{j=1}^{N} f_{i}+\varepsilon_{i j}$

\section{B. The dataset}

The country-pair traffic data are from IATA and are available for 2005. They were kindly provided to the author by the WTO Secretariat. ${ }^{5}$ As noted, the policy variable is the ALI, which the WTO Secretariat has constructed by selecting the provisions of bilateral ASAs deemed to be particularly important for market access. A score between zero and 8 is assigned to each restriction, with zero being the most restrictive and 8 the least restrictive. This process has been undertaken in consultation with a group of aviation experts. The ALI is the sum of scores obtained by a given ASA, and ranges between zero for very restrictive agreements and 50 for very liberal ones. ${ }^{6}$

The effective date of the ALI is 2005, so the regressions are cross-sectional. The reporters are 20 APEC countries (all members except Chinese Taipei as it is not an ICAO signatory), and the partners are all countries which have concluded bilateral ASAs with the included APEC economies. Data on control for GDP are from the World Bank development indicators. Data for geographical variables are from the Centre d'Etudes Prospectives et d'Informations Internationales (CEPII). CEPII has created and made available two datasets providing data for empirical economic research including geographical elements and variables. ${ }^{7}$ The sources include the CIA World Factbook and the website www.ethnologue.org.

\footnotetext{
${ }^{5}$ It is recognised that these data have some limitations; in particular, they do not include low-cost traffic. They are among the best available statistics, however, for bilateral passenger traffic.

${ }^{6}$ The ALI variable is converted into logarithms after adding 0.001 , in order to retain observations for which the indicator equals zero.

${ }^{7}$ See http://www.cepii.fr/anglaisgraph/bdd/distances.htm.
} 


\section{Estimation results}

The baseline regression results are presented in Table 1 below. As an initial robustness check, the estimates of the Anderson and Van Wincoop (2003) equation are compared with a range of other OLS and PPML specifications. ${ }^{8}$ The parameters are elasticities and thus provide an estimate of the percentage change in traffic as a result of $1 \%$ change in the variable in question. The models fit the data quite well, and both the R-squared and Pseudo- $\mathrm{R}^{2}$ increase considerably when country-specific factors are controlled through importer and exporter fixed effects.

Table 1. The relationship between regulation and air passenger traffic, OLS and Poisson pseudo maximum likelihood - ALI full sample (2005)

\begin{tabular}{|c|c|c|c|c|c|c|c|}
\hline \multicolumn{4}{|c|}{ Partner FE } & \multirow{2}{*}{$\begin{array}{c}\text { Partner FE } \\
\text { OLS }\end{array}$} & \multicolumn{3}{|c|}{ Reporter \& Partner FE } \\
\hline & OLS & OLS & PPML & & PPML & OLS & PPML \\
\hline Log partner GDP & $\begin{array}{r}0.681 * * * \\
(0.0317)\end{array}$ & & & $\begin{array}{r}0.695 * * * \\
(0.0293)\end{array}$ & $\begin{array}{c}1.336^{* * *} \\
(0.103)\end{array}$ & & \\
\hline Log reporter GDP & $\begin{array}{c}0.532 * * * \\
(0.0321)\end{array}$ & $\begin{array}{c}0.596 * * * \\
(0.0333)\end{array}$ & $\begin{array}{l}1.277 * * * \\
(0.0816)\end{array}$ & & & & \\
\hline Log distance & $\begin{array}{c}-0.892 * * * \\
(0.105)\end{array}$ & $\begin{array}{c}-0.861 * * * \\
(0.112)\end{array}$ & $\begin{array}{c}-1.418 * * * \\
(0.453)\end{array}$ & $\begin{array}{c}-1.327 * * * \\
(0.109)\end{array}$ & $\begin{array}{c}-2.488 * * * \\
(0.215)\end{array}$ & $\begin{array}{c}-1.263 * * * \\
(0.113)\end{array}$ & $\begin{array}{c}-2.022 * * * \\
(0.152)\end{array}$ \\
\hline Common language & $\begin{array}{c}0.423 * * * \\
(0.0487)\end{array}$ & $\begin{array}{c}0.541 * * * \\
(0.0687)\end{array}$ & $\begin{array}{c}0.632 * * * \\
(0.184)\end{array}$ & $\begin{array}{r}0.238 * * * \\
(0.0493)\end{array}$ & $\begin{array}{c}0.590 * * * \\
(0.170)\end{array}$ & $\begin{array}{r}0.276^{* * *} \\
(0.0583)\end{array}$ & $\begin{array}{c}0.447 * * * \\
(0.157)\end{array}$ \\
\hline Historic tie & $\begin{array}{c}0.141 \\
(0.108)\end{array}$ & $\begin{array}{l}0.257^{*} \\
(0.133)\end{array}$ & $\begin{array}{c}0.539 * * * \\
(0.199)\end{array}$ & $\begin{array}{c}0.250 * * \\
(0.107)\end{array}$ & $\begin{array}{c}0.261 \\
(0.228)\end{array}$ & $\begin{array}{c}0.381 * * * \\
(0.120)\end{array}$ & $\begin{array}{c}0.519 * * * \\
(0.152)\end{array}$ \\
\hline Border & $\begin{array}{c}0.117 \\
(0.136)\end{array}$ & $\begin{array}{l}0.259^{*} \\
(0.147)\end{array}$ & $\begin{array}{l}0.0896 \\
(0.601)\end{array}$ & $\begin{array}{r}-0.0845 \\
(0.156)\end{array}$ & $\begin{array}{l}-0.177 \\
(0.301)\end{array}$ & $\begin{array}{c}0.169 \\
(0.149)\end{array}$ & $\begin{array}{l}0.0450 \\
(0.186)\end{array}$ \\
\hline $\begin{array}{l}\text { Existing direct } \\
\text { service }\end{array}$ & $\begin{array}{c}0.850 * * * \\
(0.0546)\end{array}$ & $\begin{array}{c}0.764 * * * \\
(0.0645)\end{array}$ & $\begin{array}{c}1.377 * * * \\
(0.167)\end{array}$ & $\begin{array}{c}0.738 * * * \\
(0.0502)\end{array}$ & $\begin{array}{c}1.600 * * * \\
(0.110)\end{array}$ & $\begin{array}{c}0.679 * * * \\
(0.0550)\end{array}$ & $\begin{array}{c}1.285^{* * *} * \\
(0.127)\end{array}$ \\
\hline Reporter island & $\begin{array}{c}0.324 * * * \\
(0.0488)\end{array}$ & $\begin{array}{c}0.212 * * * \\
(0.0494)\end{array}$ & $\begin{array}{l}0.0880 \\
(0.144)\end{array}$ & & & & \\
\hline Partner island & $\begin{array}{c}0.318 * * * \\
(0.0611)\end{array}$ & & & $\begin{array}{c}0.325 * * * \\
(0.0516)\end{array}$ & $\begin{array}{c}0.443 * * * \\
(0.125)\end{array}$ & & \\
\hline Log ALI & $\begin{array}{c}0.0665^{* * * *} \\
(0.0250)\end{array}$ & $\begin{array}{c}0.0746 * * * \\
(0.0235)\end{array}$ & $\begin{array}{c}0.113 * * * \\
(0.0391)\end{array}$ & $\begin{array}{c}0.0520 * * \\
(0.0232)\end{array}$ & $\begin{array}{l}0.185^{*} \\
(0.102)\end{array}$ & $\begin{array}{c}0.0455^{* *} \\
(0.0196)\end{array}$ & $\begin{array}{c}0.0402 \\
(0.0432)\end{array}$ \\
\hline Observations & 647 & 681 & 688 & 647 & 651 & 750 & 757 \\
\hline R-squared & 0.766 & 0.866 & & 0.845 & & 0.917 & \\
\hline Pseudo-R ${ }^{2}$ & & & 0.911 & & 0.860 & & 0.947 \\
\hline Prob. (H0: PPML) & & & $0.000 * * *$ & & $0.000 * * *$ & & $0.000 * * *$ \\
\hline
\end{tabular}

Note: Robust standard errors reported in parenthesis. Statistical significance as follows: *** (1\%), ** $(5 \%)$, and * (10\%).

\footnotetext{
${ }^{8}$ The number of observations does not change very much as there are very few zeros in the dataset.
} 
The core gravity variables are economically and statistically significant and they exhibit the expected signs. Larger countries trade more while distance adversely affects traffic. Island countries also trade more as substitute modes of transport are less feasible, as do economies that share the same language. The other geographical and historical controls have for the most part the expected signs, but are generally more precisely estimated with OLS. As expected, having a direct service considerably increases bilateral traffic flows.

The ALI coefficient is both statistically significant and with the expected sign in all specifications, except for the one using the PPML with partner and reporter fixed effects. To test whether the PPML is an appropriate estimator, the fitted values are used to perform a Park test (Santos Silva and Tenreyro, 2006, Eq. 13). The null hypothesis for this test is that the Poisson model is adequate. The results provide strong evidence that the PPML is not appropriate for this dataset, and that

Table 2. The relationship between regulation and air passenger traffic, OLS - ALI direct service sample (2005)

\begin{tabular}{|c|c|c|c|c|}
\hline & & Partner FE & Reporter & FE Reporter \& Partner FE \\
\hline Log partner GDP & $\begin{array}{c}0.569 * * * \\
(0.0306)\end{array}$ & & $\begin{array}{r}0.611 * * * \\
(0.0322)\end{array}$ & \\
\hline Log reporter GDP & $\begin{array}{c}0.436^{* * *} \\
(0.0363)\end{array}$ & $\begin{array}{c}0.563 * * * \\
(0.0427)\end{array}$ & & \\
\hline Log distance & $\begin{array}{c}-1.022 * * * \\
(0.0913)\end{array}$ & $\begin{array}{c}-0.942 * * * \\
(0.110)\end{array}$ & $\begin{array}{c}-1.380 * * * \\
(0.107)\end{array}$ & $\begin{array}{c}-1.253 * * * \\
(0.113)\end{array}$ \\
\hline Common language & $\begin{array}{c}0.381 * * * \\
(0.0538)\end{array}$ & $\begin{array}{c}0.442 * * * \\
(0.0757)\end{array}$ & $\begin{array}{r}0.250 * * * \\
(0.0554)\end{array}$ & $\begin{array}{c}0.268 * * * \\
(0.0587)\end{array}$ \\
\hline Historic tie & $\begin{array}{l}0.212 * * \\
(0.0975)\end{array}$ & $\begin{array}{r}0.322 * * \\
(0.129)\end{array}$ & $\begin{array}{r}0.332 * * * \\
(0.0971)\end{array}$ & $\begin{array}{c}0.443 * * * \\
(0.120)\end{array}$ \\
\hline Border & $\begin{array}{c}-0.00492 \\
(0.127)\end{array}$ & $\begin{array}{l}0.0687 \\
(0.117)\end{array}$ & $\begin{array}{l}0.0922 \\
(0.147)\end{array}$ & $\begin{array}{c}-0.00375 \\
(0.119)\end{array}$ \\
\hline Reporter island & $\begin{array}{c}0.237 * * * \\
(0.0596)\end{array}$ & $\begin{array}{c}0.0838 \\
(0.0592)\end{array}$ & & \\
\hline Partner island & $\begin{array}{c}0.259 * * * \\
(0.0660)\end{array}$ & & $\begin{array}{c}0.246 * * * \\
(0.0577)\end{array}$ & \\
\hline Log ALI & $\begin{array}{c}0.0944 * * * \\
(0.0337)\end{array}$ & $\begin{array}{c}0.0676 * * \\
(0.0322)\end{array}$ & $\begin{array}{c}0.100^{* * *} \\
(0.0317)\end{array}$ & $\begin{array}{l}0.0477 * \\
(0.0248)\end{array}$ \\
\hline Observations & 381 & 392 & 381 & 426 \\
\hline R-squared & 0.595 & 0.802 & 0.724 & 0.883 \\
\hline Prob. (H0: PPML) & $0.000 * * *$ & $0.000 * * *$ & $0.000 * * *$ & $0.000 * *$ \\
\hline
\end{tabular}

Note: Robust standard errors reported in parenthesis. Statistical significance as follows: $* * *(1 \%)$, ** $(5 \%)$, and * $(10 \%)$. 
the assumption regarding the pattern of heteroskedasticity is incorrect: the null hypothesis is systematically rejected at $1 \%$ level.

Hence, it is better to rely on OLS estimates for the data used here. The preferred specification, the Anderson and Van Wincoop (2003) equation, provides the most conservative estimates. Prior to taking account of general equilibrium effects, the results imply that if a country pair eased restrictions to double its ALI score, traffic would increase by $4.5 \%$.

\section{Robustness checks}

The previous regressions are estimated using all APEC country pairs (with other APEC economies as well as non-members) for which the ALI is available.

Table 3. The relationship between regulation and air passenger traffic, OLS - ALI 5th full sample (2005)

\begin{tabular}{|c|c|c|c|c|}
\hline & & Partner FE & Reporter FE & Reporter \& Partner FE \\
\hline Log partner GDP & $\begin{array}{c}0.681 * * * \\
(0.0317)\end{array}$ & & $\begin{array}{c}0.695 * * * \\
(0.0293)\end{array}$ & \\
\hline Log reporter GDP & $\begin{array}{c}0.533 * * * \\
(0.0321)\end{array}$ & $\begin{array}{c}0.596 * * * \\
(0.0333)\end{array}$ & & \\
\hline Log distance & $\begin{array}{c}-0.891 * * * \\
(0.105)\end{array}$ & $\begin{array}{c}-0.859 * * * \\
(0.112)\end{array}$ & $\begin{array}{c}-1.328 * * * \\
(0.109)\end{array}$ & $\begin{array}{c}-1.264 * * * \\
(0.113)\end{array}$ \\
\hline Common language & $\begin{array}{c}0.426^{* * *} \\
(0.0487)\end{array}$ & $\begin{array}{c}0.543 * * * \\
(0.0687)\end{array}$ & $\begin{array}{c}0.239 * * * \\
(0.0493)\end{array}$ & $\begin{array}{r}0.275 * * * \\
(0.0583)\end{array}$ \\
\hline Historic tie & $\begin{array}{c}0.141 \\
(0.108)\end{array}$ & $\begin{array}{l}0.256 * \\
(0.133)\end{array}$ & $\begin{array}{c}0.252 * * \\
(0.107)\end{array}$ & $\begin{array}{c}0.382 * * * \\
(0.120)\end{array}$ \\
\hline Border & $\begin{array}{c}0.114 \\
(0.137)\end{array}$ & $\begin{array}{l}0.257 * \\
(0.147)\end{array}$ & $\begin{array}{c}-0.0836 \\
(0.157)\end{array}$ & $\begin{array}{c}0.170 \\
(0.150)\end{array}$ \\
\hline Exisitng direct service & $\begin{array}{c}0.851 * * * \\
(0.0545)\end{array}$ & $\begin{array}{c}0.765 * * * \\
(0.0645)\end{array}$ & $\begin{array}{r}0.738 * * * \\
(0.0502)\end{array}$ & $\begin{array}{r}0.679 * * * \\
(0.0550)\end{array}$ \\
\hline Reporter island & $\begin{array}{c}0.322 * * * \\
(0.0490)\end{array}$ & $\begin{array}{r}0.210 * * * \\
(0.0497)\end{array}$ & & \\
\hline Partner island & $\begin{array}{c}0.318 * * * \\
(0.0611)\end{array}$ & & $\begin{array}{c}0.325 * * * \\
(0.0516)\end{array}$ & \\
\hline Log ALI 5th & $\begin{array}{c}0.0599 * * \\
(0.0242)\end{array}$ & $\begin{array}{c}0.0684 * * * \\
(0.0227)\end{array}$ & $\begin{array}{c}0.0486^{* *} \\
(0.0220)\end{array}$ & $\begin{array}{c}0.0426^{* *} \\
(0.0187)\end{array}$ \\
\hline Observations & 647 & 681 & 647 & 750 \\
\hline R-squared & 0.766 & 0.866 & 0.845 & 0.916 \\
\hline Prob. (H0: PPML) & $0.000 * * *$ & $0.000 * * *$ & $0.000 * * *$ & $0.000 * * *$ \\
\hline
\end{tabular}

Note: Robust standard errors reported in parenthesis. Statistical significance as follows: $* * *(1 \%)$, ** $(5 \%)$, and * $(10 \%)$. 
Air Passenger Transport In The Apec: Regulatory Impacts and Prospects for Asia Pacific 323

Table 4. The relationship between regulation and air passenger traffic, OLS - ALI Own full sample (2005)

\begin{tabular}{|c|c|c|c|c|}
\hline & & Partner FE & Reporter FE & Reporter \& Partner FE \\
\hline Log partner GDP & $\begin{array}{c}0.680 * * * \\
(0.0316)\end{array}$ & & $\begin{array}{c}0.695 * * * \\
(0.0293)\end{array}$ & \\
\hline Log reporter GDP & $\begin{array}{c}0.533 * * * \\
(0.0320)\end{array}$ & $\begin{array}{c}0.597 * * * \\
(0.0333)\end{array}$ & & \\
\hline Log distance & $\begin{array}{c}-0.891 * * * \\
(0.106)\end{array}$ & $\begin{array}{c}-0.861 * * * \\
(0.112)\end{array}$ & $\begin{array}{c}-1.326^{* * *} \\
(0.109)\end{array}$ & $\begin{array}{c}-1.262 * * * \\
(0.113)\end{array}$ \\
\hline Common language & $\begin{array}{l}0.421 * * * \\
(0.0486)\end{array}$ & $\begin{array}{c}0.539 * * * \\
(0.0687)\end{array}$ & $\begin{array}{c}0.239 * * * \\
(0.0493)\end{array}$ & $\begin{array}{c}0.276^{* * *} * \\
(0.0583)\end{array}$ \\
\hline Historic tie & $\begin{array}{c}0.143 \\
(0.109)\end{array}$ & $\begin{array}{l}0.258 * \\
(0.133)\end{array}$ & $\begin{array}{c}0.250 * * \\
(0.107)\end{array}$ & $\begin{array}{c}0.381 * * * \\
(0.120)\end{array}$ \\
\hline Border & $\begin{array}{c}0.121 \\
(0.136)\end{array}$ & $\begin{array}{c}0.262 * \\
(0.147)\end{array}$ & $\begin{array}{r}-0.0842 \\
(0.156)\end{array}$ & $\begin{array}{c}0.170 \\
(0.149)\end{array}$ \\
\hline Exisitng direct service & $\begin{array}{c}0.849 * * * \\
(0.0546)\end{array}$ & $\begin{array}{r}0.764 * * * \\
(0.0645)\end{array}$ & $\begin{array}{r}0.738 * * * \\
(0.0503)\end{array}$ & $\begin{array}{c}0.679 * * * \\
(0.0550)\end{array}$ \\
\hline Reporter island & $\begin{array}{c}0.325 * * * \\
(0.0486)\end{array}$ & $\begin{array}{c}0.214 * * * \\
(0.0491)\end{array}$ & & \\
\hline Partner island & $\begin{array}{c}0.319^{* * *} * \\
(0.0611)\end{array}$ & & $\begin{array}{c}0.326 * * * \\
(0.0516)\end{array}$ & \\
\hline Log ALI own & $\begin{array}{c}0.0700 * * * \\
(0.0252)\end{array}$ & $\begin{array}{c}0.0781 * * * \\
(0.0237)\end{array}$ & $\begin{array}{c}0.0508 * * \\
(0.0238)\end{array}$ & $\begin{array}{c}0.0453 * * \\
(0.0200)\end{array}$ \\
\hline Observations & 647 & 681 & 647 & 750 \\
\hline R-squared & 0.767 & 0.866 & 0.845 & 0.916 \\
\hline Prob. (H0: PPML) & $0.000 * * *$ & $0.000 * * *$ & $.000 * * *$ & $00.000 * * *$ \\
\hline
\end{tabular}

Note: Robust standard errors reported in parenthesis. Statistical significance as follows: *** (1\%), ** $(5 \%)$, and * $(10 \%)$.

However, not all of these aviation partners may have a bilateral link, as passengers may transit through a regional hub before reaching their final destination. The regressions presented above this possibility is accounted for by the dummy existing direct service. To investigate this further, the regressions in Table 1 are re-run for a sub-sample that includes only country pairs with a direct air service (Table 2). For these estimates and in what follows, the analysis reports OLS results only and includes the probability values associated with the PPML test statistics.

Although as expected the coefficients in the direct service sub-sample are in general greater, both values and statistical significance are broadly comparable in the two samples. Notably, the magnitude of the ALI coefficients in the preferred specifications is very similar in both samples.

Another important robustness check relates to the measurement of policy 
Table 5. The relationship between regulation and air passenger traffic, OLS - ALI Des full sample (2005)

\begin{tabular}{lcccc}
\hline & & Partner FE & Reporter FE & Reporter \& Partner FE \\
\hline Log partner GDP & $0.680^{* * *}$ & & $0.694^{* * *}$ & \\
& $(0.0316)$ & & $(0.0292)$ & \\
Log reporter GDP & $0.533^{* * *}$ & $0.596^{* * *}$ & & \\
& $(0.0321)$ & $(0.0333)$ & & $-1.262^{* * *}$ \\
Log distance & $-0.893^{* * *}$ & $-0.861^{* * *}$ & $-1.328^{* * *}$ & $(0.112)$ \\
& $(0.105)$ & $(0.111)$ & $(0.109)$ & $0.276^{* * *}$ \\
Common language & $0.423^{* * *}$ & $0.541^{* * *}$ & $0.238^{* * *}$ & $(0.0583)$ \\
& $(0.0486)$ & $(0.0687)$ & $(0.0493)$ & $0.381 * * *$ \\
Historic tie & 0.140 & $0.257^{*}$ & $0.250^{* *}$ & $(0.120)$ \\
& $(0.109)$ & $(0.133)$ & $(0.107)$ & 0.167 \\
Border & 0.115 & $0.256^{*}$ & -0.0865 & $(0.149)$ \\
& $(0.136)$ & $(0.147)$ & $(0.156)$ & $0.680^{* * *}$ \\
Exisitng direct service & $0.850^{* * *}$ & $0.765^{* * *}$ & $0.738^{* * *}$ & $(0.0549)$ \\
& $(0.0545)$ & $(0.0644)$ & $(0.0501)$ & \\
Reporter island & $0.324^{* * *}$ & $0.213^{* * *}$ & & \\
& $(0.0487)$ & $(0.0493)$ & & \\
Partner island & $0.318^{* * *}$ & & $0.325^{* * *}$ & \\
& $(0.0611)$ & & $(0.0516)$ & \\
Log ALI des & $0.0679^{* * *}$ & $0.0749^{* * *}$ & $0.0537^{* *}$ & $0.0455^{* *}$ \\
Observations & $(0.0246)$ & $(0.0233)$ & $(0.0229)$ & $(0.0193)$ \\
R-squared & 647 & 681 & 647 & 750 \\
Prob. (H0: PPML) & 0.767 & 0.866 & 0.845 & 0.917 \\
\hline
\end{tabular}

Note: Robust standard errors reported in parenthesis. Statistical significance as follows: *** $(1 \%)$, ** $(5 \%)$, and * $(10 \%)$.

restrictiveness, in particular to whether the relative effects of different regulatory measures may be better captured using a different set of weights. ${ }^{9}$ To examine whether the findings presented here are robust to these considerations, the models are re-estimated with three alternative weighting schemes to construct the ALI. These have been developed by the WTO Secretariat to take into account the specific situation of different country pairs.

In particular, more weight can be assigned to: 1) $5^{\text {th }}$ freedom traffic rights (e.g., for geographically remote countries such as Australia and New Zealand); 2) withholding, in particular, the community of interest and principal place of

${ }^{9}$ Multicollinearity has prevented identification of the effects of specific measures on traffic. 
business; and 3) multiple designations. The estimates are presented in Tables 3-5 below, indicating that all results hold when the regressions are re-run using the three variants of the ALI. ${ }^{10}$

\section{Conclusion}

Trade in air passenger transport plays an increasingly important role in the ongoing integration of APEC economies. The sector is traded not only in its own right but is an intermediate service for other kinds of trade recognized of growing importance in the Asia Pacific region, particularly tourism. This study shows that air transport has undergone solid expansion in the region, notwithstanding the intervention of major external events. In light of its increasing economic importance, population, and geography, Asia Pacific is predicted to become the largest world air transport market in the near future. The region therefore seems well placed to benefit from future bilateral and multilateral reforms to lower trade costs.

Efforts under the auspices of APEC and other regional fora have laid down the ground for the progressive liberalization of air transport within the region. Some progress has already been achieved in easing restrictions by APEC economies within the bilateral framework, particularly through the emergence of open skies agreements over the last decades. Yet, more needs to be done with respect to liberal traffic rights, open routes, tariffs, and capacity requirements. Furthermore, ownership and control rules represent perhaps the most difficult issue to tackle, with most ASAs maintaining a conservative approach in this area. Further headway achieved in the region's plurilateral ASAs could provide momentum for advancing reforms.

\footnotetext{
${ }^{10}$ Further results (available on request) show that these findings are also robust to the possible endogeneity of the ALI to passenger traffic. The average ethics index of each country pair is an adequate instrument for the degree of bilateral liberalization. Two such indices, the Public Sector Ethics Index and the Judicial/Legal Effectiveness Index, developed in Daniel Kaufmann's Chapter of the World Bank Competitiveness Report 2004/2005 (Kaufmann, 2004), are strongly correlated with the ALI: first stage $\mathrm{F}=12.98^{* * *}$ and $\mathrm{F}=14.17^{* * *}$, respectively. Less corrupt countries and with effective judicial systems tend to be more liberal. Moreover, these indices should not affect bilateral traffic except through the degree of aviation market liberalization, so they therefore satisfy the excludability restriction on instrument validity as well. Running two stage least squares on the data gives an ALI coefficient that is statistically significant at $1 \%$ level in both cases. However, a large share of observations is lost due to collinearity with the country dummies. Hence, it is preferable to rely on the estimations presented here rather than on instrumental variable results.
} 
The empirical analysis carried out in this study provides evidence on the importance of reducing air transport services impediments to enhance international trade in the APEC region. Estimates from the gravity model find a positive and statistically significant relationship between relaxing bilateral air services restrictions and air passenger traffic. The results hold for a wide range of specifications controlling for fixed effects, different sample sizes, and for all variants of the ALI. The preferred specification, the Anderson and Van Wincoop (2003) equation, provides the most conservative estimates. Prior to taking account of general equilibrium effects, the results imply that if APEC economies eased air transport restrictions to double the ALI scores with their aviation partners, both within and outside the APEC region, traffic would increase by $4.5 \%$.

\section{Acknowledgements}

The views expressed here are the author's own and should not be attributed to the OECD. The author is grateful to Ben Shepherd for suggestions and comments on this paper. He also wishes to express his gratitude to Pierre Latrille and Antonia Carzaniga for their support in making this paper possible, and to Christopher Findlay and Patrick Jomini for helpful discussions during the preparation of the study.

Received 1 July 2011, Revised 28 March 2012, Accepted 21 April 2012

\section{References}

Achard, P. (2009), "The Regulation of International Air Cargo Services", Master Thesis, Groupe d'Economie Mondiale, Sciences Po.

Anderson, J.E. and E. Van Wincoop (2003), "Gravity with Gravitas: A Solution to the Border Puzzle", The American Economic Review, Vol 93 No. 1, 170-192.

Baldwin, R. and D. Taglioni (2006), "Gravity for Dummies and Dummies for Gravity Equations", NBER Working Paper 12516, available at: www.nber.org/papers/ w12516.

Centre for Asia Pacific Aviation (CAPA) (2007), "Liberalisation of Air Services in the APEC Region, 1995-2005", APEC Transportation Working Group and the Australian Department of Transport and Regional Services.

Doove, S., Gabbitas, O., Nguyen-Hong, D., and Owen, J. (2001), "Price Effects of Regulation: International Air Passenger Transport, Telecommunications and Electricity Supply", Productivity Commission Staff Research Paper, Canberra. 
Findlay, C. and D. Round (2006), “The 'Three Pillars of Stagnation': Challenges for Air Transport Reform", Issues in International Competition Policy Cooperation”, World Trade Review, (2006) 5: 2, 251-270.

Geloso Grosso, M and B. Shepherd (2011), "Air Cargo Transport in APEC: Regulation and Effects on Merchandise Trade", Journal of Asian Economics 22 (2011) 203212.

Gonenc, R., and Nicoletti, G. (2000), "Regulation, Market Structure and Performance in Air Passenger Transport", OECD, Paris.

Kauffman, D. (2004), "Corruption, Governance and Security: Challenges for the Rich Countries and the World", Chapter in the World Bank Competitiveness Report 2004/ 2005, available at: http://web.worldbank.org/WBSITE/EXTERNAL/WBI/ EXTWBIGOVANTCOR/0,,contentMDK:20788416 pagePK:64168445 piPK: 64168309 theSitePK:1740530,00.html.

Micco, A. and T. Serebrisky (2004), "Infrastructure, Competition Regimes, and Air Transport Costs: Cross-Country Evidence", World Bank Policy Research Working Paper no. 3355, available at SSRN: http://ssrn.com/abstract=610399.

Pacific Asia Travel Association (PATA) (2007), "The Non-Hub Story”, Issues and Trends, Volume 13, Issue 3 March 2007.

Piermartini, R., and L. Rousova (2008), "Liberalisation of Air Transport Services and Passenger Traffic", Staff Working Paper ERSD-2008-06, World Trade Organisation, December 2008.

Santos, S. and S. Tenreyro (2006), "The Log of Gravity", Review of Economics and Statistics, November 2006, 88(4): 641-658.

UNESCAP (2005), "Major Issues in Tourism Development in the Asian and Pacific Region", Note by the Secretariat E/ESCAP/STD/2.

WTO (2006), "Second Review of the Air Transport Annex: Developments in the Air Transport Sector (Part II). Quantitative Air Service Agreements Review (QUASAR) (Volumes I and II): Note by the Secretariat", document S/C/W/270.

WTO (2007), "Second Review of the Air Transport Annex: Developments in the Air Transport Sector (Part III): Note by the Secretariat", document S/C/W/270/Add.2.

Zainal-Abidin, M., W. K. Wan Mohd Nawawi, and S. Kamaruddin (2005), "Strategic Directions for ASEAN Airlines in a Globalising World: Ownership Rules and Investment Issues, REPSF Project no. 04/008. 